\title{
INVESTIGATION OF THERMOPHYSICAL PROPERTIES OF HEAT-INSULATING BARRIER MANUFACTURED BY INCREMENTAL RAPID PROTOTYPING METHOD
}

\begin{abstract}
This paper presents the results of experimental investigation of thermophysical properties of material manufactured with 3D printing technology with the use of fused deposition modelling (FDM) method. Cylindrically shaped samples with a diameter of $50.8 \mathrm{~mm}$ and with various fill density (from 10 to $100 \%$ ) were prepared. The investigated material was PLA (polylactic acid, polylactide). The investigation was carried out in order to determine the density, thermal conductivity, thermal diffusivity and specific heat of tested material. The main aim of this paper was to determine the influence of fill density on thermal conductivity. The results can be useful in designing thermal insulation manufactured with rapid prototyping methods, operating in relative low temperature conditions $\left(<100^{\circ} \mathrm{C}\right)$.
\end{abstract}

Keywords: rapid prototyping, FDM technology, thermal conductivity, 3D printing

\section{Introduction}

Thermal insulation currently plays a special role in many industries, including construction, heating and engineering. Available technological solutions that can reduce energy consumption and heat loss are still being improved. The improvements are made mainly at the material level by searching for materials with the lowest possible thermal conductivity and fast, economical and reliable methods of their manufacturing. One of the production concepts is the use of 3D printing technology, which now plays a significant role in the production of various types of products, mainly for objects with complex shapes. With rapid prototyping techniques it is possible to view a real part of a previously designed model. Among the variety of rapid prototyping methods, the fused deposition modeling method is the most commonly used because of its simplicity and

\footnotetext{
1 Autor do korespondencji/corresponding author: Paweł Gil, Rzeszow University of Technology, 12 Powstańców Warszawy Ave., 35-959 Rzeszów, tel.: (17) 7432299, e-mail: gilpawel@prz. edu.pl

2 Maria Tychanicz, Rzeszow University of Technology, e-mail: mtychanicz@prz.edu.pl
} 
versatility [1]. This method was developed in the 1980s. This method has plenty of advantages including the availability of a wide range of thermoplastics, mainly from the group of polymers from which the final prototype is made. The choice of filament type is dictated mainly by the type and purpose of the design part. The most commonly used materials are acrylonitrile butadiene styrene (ABS) [2, 3], polylactide (PLA) [4] and sometimes polypropylene [5]. PLA is used more often in technical applications. This material belongs to the group of biodegradable aliphatic polyesters of organic origin. PLAs has a wide range of applications, ranging from medicine, due to bio-compatible properties [6, 7], to packaging, electronics, etc. PLA can be manufactured with the addition of various types of fillers. The thermal properties of polylactide show that it can also be used as a raw material for the production of various types of insulation barriers. The thermal conductivity of pure polylactide is about $0.193 \mathrm{~W} /(\mathrm{m} \cdot \mathrm{K})$ [8], which classifies this material in a group of heat-insulating materials. A special feature of the FDM method is the ability to control the properties of the manufactured part, such as mechanical properties, density, internal structure, porosity [5]. In the most of experimental work concerning the FDM method, the authors focus on investigating the influence of technological parameters on the mechanical properties of products while their impact on thermal properties is largely neglected. The porosity of the materials used for thermal insulation plays a significant role due to its influence on the thermal conductivity of the material. The pores inside the material form air cells whose size and shape determine the value of the coefficient of thermal conductivity. At elevated temperatures, the heat transfer inside the porous material is complex and occurs through conduction, convection and radiation. In the context of general proceedings focused on heat loss reduction, it is important to determine the relationship between porosity and thermophysical properties of the obtained product. These relationships were previously analyzed and developed by experimental, analytical and numerical methods. Based on them it was shown that not only the pore volume contribute to thermal conductivity, but also pore shape, size, orientation, their degree of order and emissivity. In the paper [9], the authors presented the results of experimental investigation of the effect of porosity on thermal conductivity of cubes made of materials with various thermal conductivity. The investigation of thermal conductivity was performed on the cubic samples, in which a series of holes of different diameters were drilled randomly and orderly. Therefore, a porous structure with cylindrical and spherical pores were obtained. The results of the measurement carried out with varying temperature conditions show that both with the increase of the porosity and the temperature of the measurement, the thermal conductivity decreases nonlinearly with respect to the solid material. In addition, the degree of thermal conductivity reduction of the samples in which the pores were randomly oriented, is proportional to the volume fraction of the pores in the material. The results were also compared with the developed theoretical model of the dependence of thermal conductivity on porosity of the material. The production of materials using rapid 
prototyping techniques, as an alternative to standard technologies, offers the opportunity to obtain the final product with predicted properties achieved by controlling the technological parameters. The use of polymeric materials in rapid prototyping methods to obtain products for thermal insulation requires that their working temperature is as low as possible because of the low melting point of most plastics. That is why the influence of temperature on thermal conductivity will not be particularly significant. In this paper the results of experimental studies of thermophysical properties of PLA samples made by the FDM method were presented. The samples were produced with a variable fill density coefficient $\varepsilon$ in the range of $10-100 \%$. In this way the porosity parameter was steered. The internal structure of material had an ordered grid shape. The thermal conductivity, thermal diffusivity and specific heat were measured. In addition, the density of material was determined. The measured parameters allowed to pre-determine the effect of the fill density coefficient on the thermophysical parameters of the finished product, which will allow for further verification of the suitability of the proposed concept in thermal insulation applications.

\section{Experimental set-up}

Measurement of thermal conductivity coefficient was conducted using a Unitherm 2022 instrument (Fig. 1). The model 2022 is a fully automated system and it is used for measuring the thermal conductivity of such materials like metals, ceramics, polymers, composites, glass, rubber and graphite products. The Model 2022 can be also used for testing thin specimens like paper products or plastic films. Thermal conductivity is measured according to ASTM E1530 standard aimed at evaluating the resistance to thermal transmission of materials by guarded heat flow meter method. The view of the experimental test stand is presented in Fig. 2. A specimen of the investigated material is held under a reproducible compressive load between two polished metal surfaces, each controlled at a different temperature. The lower contact surface is a part of a calibrated heat flux meter. As heat flows from the upper surface through the specimen to the lower surface, an axial temperature gradient is established in the stack. By measuring the temperature difference across the specimen (between the upper and the lower surface plates in contact with the specimen) along with the output from the heat flux transducer, thermal conductivity of the specimen can be determined when its thickness is known. A unitherm 2022 instrument is used to measure the thermal conductivity in the range of $0.1-40 \mathrm{~W} /(\mathrm{m} \cdot \mathrm{K})$ and in the temperature range of $20-300^{\circ} \mathrm{C}[10]$. The specimen of the test material has a shape of a cylinder with a diameter of $50.8 \mathrm{~mm}$ and a height depending on the expected coefficient of thermal conductivity. If a value of coefficient of thermal conductivity is higher then the thickness of the sample must be greater, and if the material has good insulating properties then thickness of the sample must be lower, due to optimal thermal resistance. 


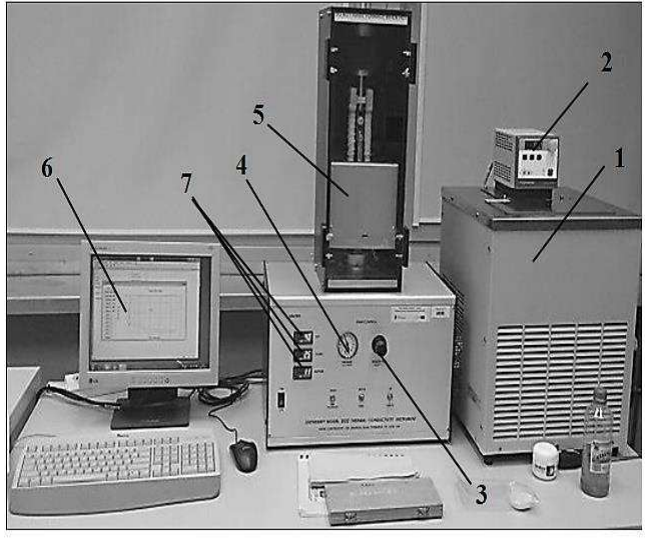

Fig. 1. The view of the experimental setup: $1-$ ultra thermostat, 2 - controller, 3 - air pressure regulator, 4 - air pressure gauge, 5 - guard furnace, 6 - computer, 7 - heater PID controllers

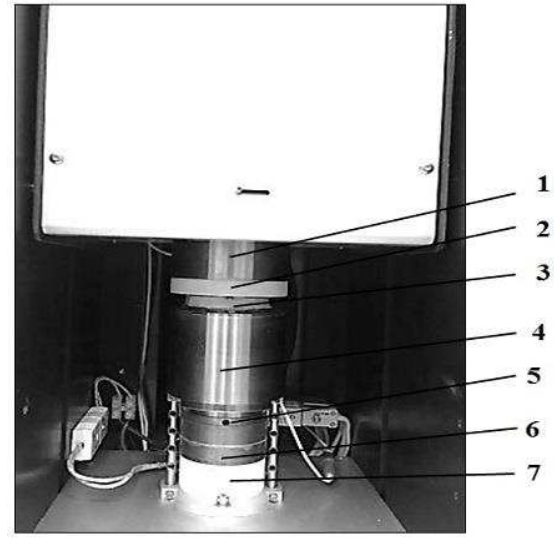

Fig. 2. The view of test stand: $1-$ top heater, 2 - upper plate, 3 - test specimen, 4 - lower plate, 5 - reference calorimeter, 6 - bottom heater, 7 - heat sink

At thermal equilibrium, the Fourier heat flow equation applied to the test specimen is as follows:

$$
R_{\mathrm{s}}=\frac{T_{\mathrm{u}}-T_{\mathrm{m}}}{q}-R_{\mathrm{int}}
$$

where: $R_{\mathrm{S}}$ - thermal resistance of the test specimen, $\mathrm{m}^{2} \cdot \mathrm{K} / \mathrm{W}$,

$T_{\mathrm{u}}$ - upper plate surface temperature, $\mathrm{K}$,

$T_{\mathrm{m}}$ - lower plate surface temperature, $\mathrm{K}$,

$q$ - heat flux through the test specimen, $\mathrm{W} / \mathrm{m}^{2}$,

$R_{\text {int }}$ - total interface resistance between specimen and surface plates, $\mathrm{m}^{2} \cdot \mathrm{K} / \mathrm{W}$.

The thermal resistance of the test specimen is defined as:

$$
R_{\mathrm{S}}=\frac{t}{k}
$$

where: $t$ - specimen thickness, $\mathrm{m}$,

$k$ - thermal conductivity, $\mathrm{W} /(\mathrm{m} \cdot \mathrm{K})$.

The heat flux through the specimen is measured with a transducer located just below the specimen. The heat flux transducer consists of a reference calorimeter with high conductivity surface plates on either side. The heat flux is determined by measuring the temperature difference across the reference calorimeter:

$$
q=\mathrm{N}\left(T_{\mathrm{m}}-T_{\mathrm{L}}\right)
$$

where: $\mathrm{N}$ - heat flux meter constant, $\mathrm{W} /\left(\mathrm{m}^{2} \cdot \mathrm{K}\right)$,

$T_{\mathrm{L}}-$ bottom heater temperature, $\mathrm{K}$. 
The specimen thermal resistance can be expressed in the form:

$$
R_{s}=\mathrm{F}\left(\frac{\Delta T_{\mathrm{s}}}{\Delta T_{\mathrm{r}}}\right)-R_{\text {int }}
$$

where: $\mathrm{F}$ - proportionality constant,

$\Delta T_{\mathrm{s}}=\left(T_{\mathrm{u}}-T_{\mathrm{m}}\right)-$ temperature drop across the specimen, $\mathrm{K}$,

$\Delta T_{\mathrm{r}}=\left(T_{\mathrm{m}}-T_{\mathrm{L}}\right)-$ temperature drop across the reference calorimeter, $\mathrm{K}$.

In order to minimize contact resistance, thermal grease is used. If the thermal resistance has been determined, the thermal conductivity can be calculated using equation (2). The measurement uncertainty of this method is usually in the range between $\pm 3 \%$ and $\pm 8 \%$ and depends on the thermal resistance of the material being tested. For each sample, three measurements of the thermal conductivity were made. Each measurement was carried out after dismantling and re-mounting of the sample in the test section (Fig. 2). The holding pressure was about 25 psi $(172 \mathrm{kPa})$. The laboratory room in which the measurements were made was air conditioned, maintaining a constant temperature and relative humidity of $20^{\circ} \mathrm{C}$ and $\mathrm{RH} 50 \%$, respectively.

The measurements of the thermal parameters were made using a KD2 Pro instrument with a two-needle probe $\mathrm{SH}-1$, which enables measurement by hot wire method. The KD2 PRO instrument is a handheld, portable meter for measuring the thermal properties of soils, solids, powders and liquid. The kit consists of a meter and sensors that are inserted into the investigated material. Two-needle sensor measures the thermal conductivity in the range of $0.02-2 \mathrm{~W} /(\mathrm{m} \cdot \mathrm{K})$, thermal diffusivity in the range of $0.1-1 \mathrm{~mm}^{2} / \mathrm{s}$ and volumetric specific heat capacity in the range of $0.5-4 \mathrm{MJ} /\left(\mathrm{m}^{3} \cdot \mathrm{K}\right)$. The measurement uncertainty of the described parameters is about $\pm 10 \%$. The probe $\mathrm{SH}-1$ enables measurement in the temperatures range from -50 to $150^{\circ} \mathrm{C}$.

A sample of solid PLA material $(\varepsilon=100 \%)$ with a diameter of $36 \mathrm{~mm}$ and a height of $40 \mathrm{~mm}$ was printed. Two parallel holes were drilled into the sample to allow the two-needle probe to be installed. The thermal grease was also used. Temperature variation was made in the air thermostat.

PLA density measurements were made by measuring the mass and volume of the investigated sample. Mass measurements were made using a RADWAG WTC2000 electronic scale with a resolution of $0.01 \mathrm{~g}$ and a maximum measuring range of $2000 \mathrm{~g}$. Volumetric measurements were made by measuring the diameter and height of the sample with the use of a micrometer. The samples are non-isotropic and the measured density should be regarded as an average values. Density measurement was carried out at ambient temperature. 


\section{Samples}

Thermo-physical properties were determined for black PLA. PLA is a fully biodegradable polymer that belongs to the aliphatic polyester group. The samples were prepared with FDM rapid prototyping method. In this method the printed material is pushed through the nozzle, heated to its melting point. The nozzle controls the flow of material and is automatically moved according to the CAM program. Wanhao Duplicator i3 3D printer with MK10 single-head extruder was used for the production of samples. The working area of the device is $200 \times 200 \times 180 \mathrm{~mm}$.

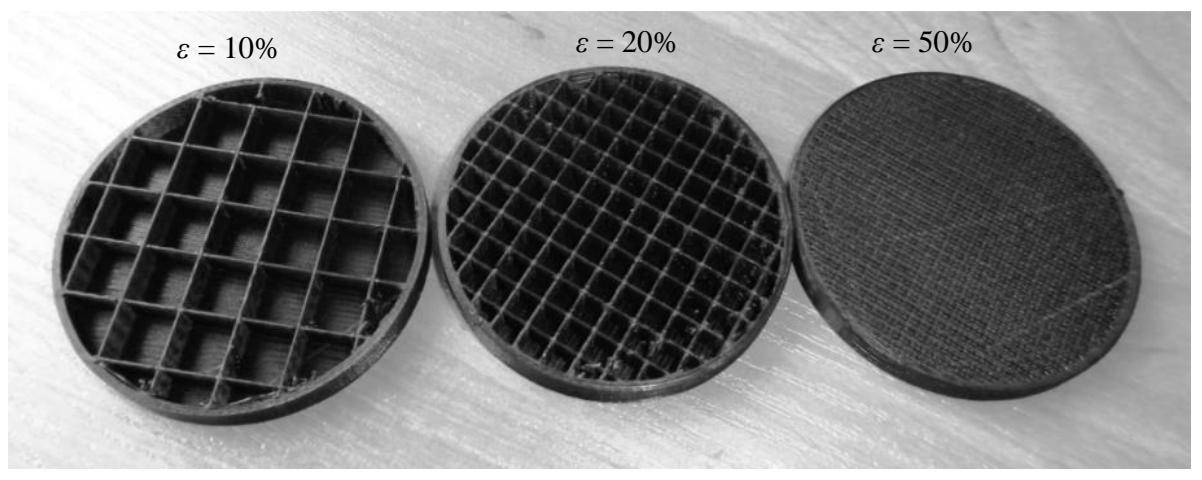

Fig. 3. Cross-sections of samples with various fill density; from left $\varepsilon=10 \%, \varepsilon=20 \%, \varepsilon=50 \%$

Ten samples with a variable fill density $\varepsilon=10-100 \%$ were printed. Cross sections of selected samples are shown in Fig. 3. Each sample has a diameter of $50.8 \mathrm{~mm}$ and height of $10 \mathrm{~mm}$. The technological parameters of the printing were as follows: the temperature of the nozzle was $195^{\circ} \mathrm{C}$ and the temperature of the bed was $50^{\circ} \mathrm{C}$. The filament diameter was $1.75 \mathrm{~mm}$. A layer thickness was set at $0.2 \mathrm{~mm}$, while wall thickness was $1.2 \mathrm{~mm}$. A print speed was $15 \mathrm{~mm} / \mathrm{s}$. The time of printing a sample with a fill density of $10 \%$ was about one hour, while for a solid sample $\varepsilon=100 \%$ it was about five hours.

\section{Results}

By varying the fill density in the range of $10-100 \%$, the average sample density was varied from $332.6 \mathrm{~kg} / \mathrm{m}^{3}$ to $1231 \mathrm{~kg} / \mathrm{m}^{3}$, as shown in Fig. 4. By reducing the fill density from 100 to $10 \%$, the density decreased 3.7 times. The rapid prototyping technology enables shortening of production time and sample mass by reducing the fill density from 100 (solid material) to $10 \%$. A five-fold reduction in production time and a three-fold decrease in mass were achieved. The dependence between density and fill density was shown in Fig. 4, this relationship is valid only for the specific sample configuration. Depending on the settings, 
especially the wall thickness, it is possible to obtain a different directional coefficient of the straight line, which will always pass through the point $\varepsilon=100 \%$ (solid material). By using thinner wall thickness it is possible to obtain a smaller weight and thus density for the same fill density.

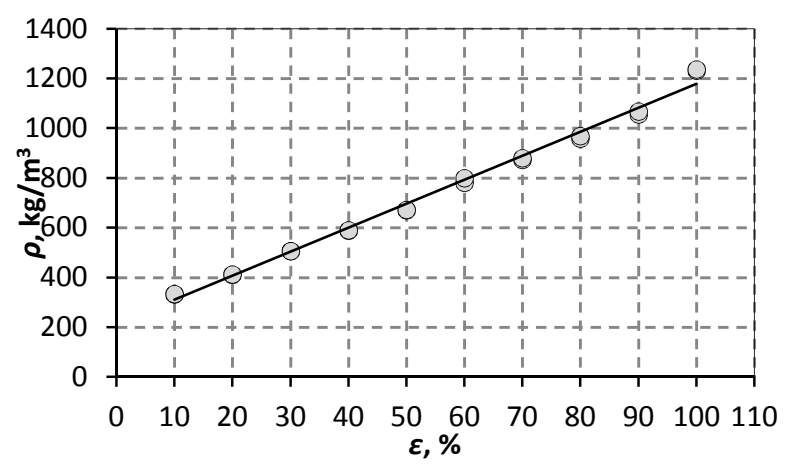

Fig. 4. Density $\rho$ as a function of fill density $\varepsilon$

Figure 5 shows the dependence of the effective thermal conductivity coefficient $k_{e}$ as a function of the density $\rho$, and as a function of the fill density $\varepsilon$. The highest value of effective thermal conductivity coefficient $k_{e}=0.21 \mathrm{~W} /(\mathrm{m} \cdot \mathrm{K})$ is for solid material (PLA $100 \%, \rho=1231 \mathrm{~kg} / \mathrm{m}^{3}$ ). By reducing the fill density $\varepsilon$, the value of the thermal conductivity decreases, reaching a local minimum at $\varepsilon=40 \%$ $k_{\mathrm{e}}=0.14 \mathrm{~W} /(\mathrm{m} \cdot \mathrm{K})$. The thermal conductivity is about $35 \%$ less than for the solid material. Below $\varepsilon<40 \%$ the value of effective thermal conductivity coefficient $k_{e}$ is stabilized at approximately $k_{\mathrm{e}} \approx 0.14 \mathrm{~W} /(\mathrm{m} \cdot \mathrm{K})$.

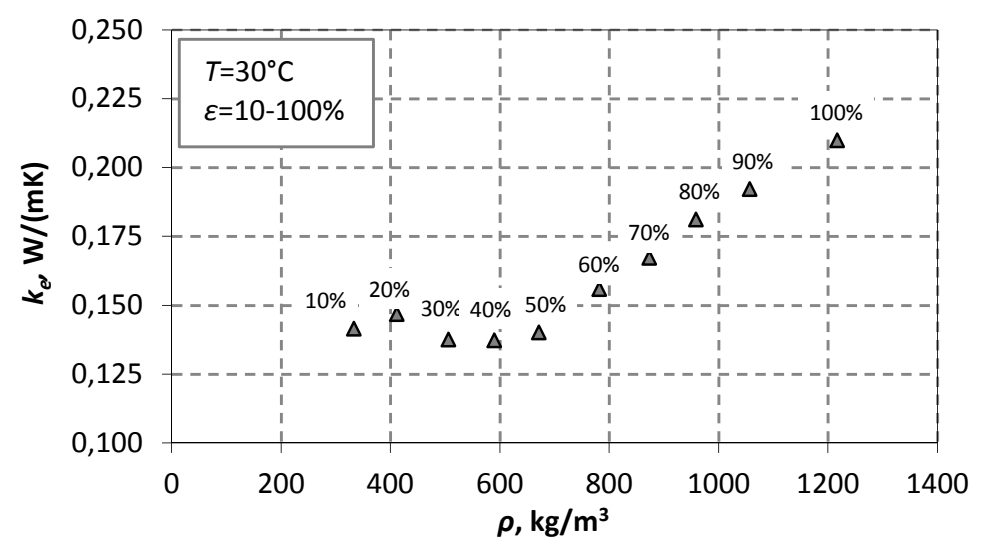

Fig. 5. Effective thermal conductivity $k_{e}$ as a function both of fill density $\varepsilon$ and density $\rho$ (measurement temperature $T=30^{\circ} \mathrm{C}$ ) 
Measurement of the thermal conductivity coefficient $k$ of solid PLA as a function of temperature reveals that there is no significant variation of this factor in this temperature range. The average value of thermal conductivity is about $0.21 \mathrm{~W} /(\mathrm{m} \cdot \mathrm{K})$ both for the hot wire and guarded heat flow meter methods.

Figure 6 shows the dependence of thermal diffusivity $a$ and volumetric specific heat $c_{\mathrm{v}}$ as a function of temperature $T$ (solid PLA). The volumetric specific heat increases as a function of temperature from $c_{\mathrm{v}}=1.9 \mathrm{MJ} /\left(\mathrm{m}^{3} \mathrm{~K}\right)$ at $T \approx 14^{\circ} \mathrm{C}$ to $c_{\mathrm{v}}=2.67 \mathrm{MJ} /\left(\mathrm{m}^{3} \cdot \mathrm{K}\right)$ at $T \approx 110^{\circ} \mathrm{C}$. The thermal diffusivity decreases as a function of temperature from $a=0.115 \mathrm{~mm}^{2} / \mathrm{s}$ at a temperature $14^{\circ} \mathrm{C}$ to $a=0.094 \mathrm{~mm}^{2} / \mathrm{s}$ at a temperature $110^{\circ} \mathrm{C}$.

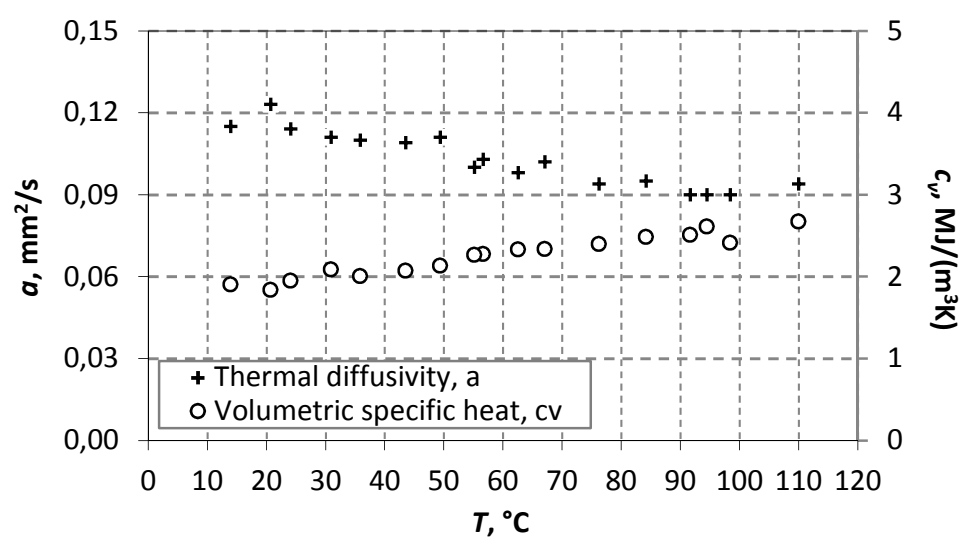

Fig. 6. Thermal diffusivity $a$ and volumetric specific heat $c_{v}$ as a function of temperature T(PLA 100\%)

\section{Conclusion}

This paper presents results of experimental investigation of thermophysical properties of PLA manufactured with rapid prototyping technology. The heat conduction was measured as a function of density and of temperature. The value of the thermal diffusivity and specific heat of the material were also measured. Table 1 presents the most important thermophysical parameters of PLA.

Table 1. Thermophysical parameters of PLA

\begin{tabular}{|l|c|c|}
\hline \multicolumn{1}{|c|}{ Name } & Symbol & Value \\
\hline Density $\left(30^{\circ} \mathrm{C}\right)$ & $\rho$ & $1231 \mathrm{~kg} / \mathrm{m}^{3}$ \\
\hline Thermal conductivity $\left(\varepsilon=100 \%, 30^{\circ} \mathrm{C}\right)$ & $k$ & $0.21 \mathrm{~W} /(\mathrm{m} \cdot \mathrm{K})$ \\
\hline Thermal diffusivity $\left(\varepsilon=100 \%, 30^{\circ} \mathrm{C}\right)$ & $a$ & $0.111 \mathrm{~mm} / \mathrm{s}$ \\
\hline Volume specific heat $\left(\varepsilon=100 \%, 30^{\circ} \mathrm{C}\right)$ & $c_{\mathrm{v}}$ & $2.09 \mathrm{MJ} /\left(\mathrm{m}^{3} \cdot \mathrm{K}\right)$ \\
\hline Specific heat $\left(\varepsilon=100 \%, 30^{\circ} \mathrm{C}\right)$ & $c$ & $1700 \mathrm{~J} /(\mathrm{kg} \cdot \mathrm{K})$ \\
\hline
\end{tabular}


Further experimental and numerical research will be carried out to develop a mathematical model describing PLA thermal parameters as a function of density and temperature.

\title{
References
}

[1] Carneiro O.S., Silva A.F., Gomes R.: Fused deposition modeling with polypropylene, Materials Design, 83 (2015) 768-776.

[2] Dawound M., Taha I., Ebeid Samy J.: Mechanical behaviour of ABS: An experimental study using FDM and injection moulding techniques, J. Manuf. Proc., 21 (2016) 39-45.

[3] Weng Z., Wang J., Senthil T., Wu L.: Mechanical and thermal properties of $\mathrm{ABS} /$ montmorillonite nanocomposites for fused deposition modeling 3D printing, Materials Design, 102 (2016) 276-283.

[4] Drummer D., Cifuentes-Cuèllar S., Rietzel D.: Suitability of PLA/TCP for fused deposition modeling, Rapid Prototyping J., 18 (2012) 500-507.

[5] Gajdoš I., Slota J.: Influence of printing conditions on structure in FDM prototypes, Tehnički vjesnik, 20 (2013) 231-236.

[6] Lebedev S.M., Gefle O.S., Amitov E.T., Berchuk D.Y., Zhuravlev D.V.: Poly(lactic acid)-based polymer composites with high electric and thermal conductivity and their characterization, Polymer Testing, 58 (2017) 241-248.

[7] Farah S., Anderson D.G., Langer R.: Physical and mechanical properties of PLA and their functions in widespread applications - A comprehensive review, Adv. Drug Delivery Rev., 107 (2016) 367-392.

[8] Frone A.N., Berlioz S., Chailan J.-F., Panaitescu D.M.: Morphology and thermal properties of PLA-cellulose nanofibers composites, Carbohydrate Polymers, 91 (2013) 377-384.

[9] Francil J., Kingery W.D.: Thermal conductivity: IX, Experimental investigation of effect of porosity on thermal conductivity, Mechanical and Thermal Properties of Ceramics Proceedings of Symposium, Gaithersburg, Maryland 1968.

[10] Tychanicz M., Smusz R.: Properties, application and thermal investigation of aerogels, ZN PRz, Mechanika, 34 (2017) 95-106.

\section{BADANIE WŁAŚCIWOŚCI TERMOFIZYCZNYCH PRZEGRÓD IZOLACYJNYCH WYTWARZANYCH PRZYROSTOWĄ METODA SZYBKIEGO PROTOTYPOWANIA}

\author{
Streszczenie \\ W pracy zaprezentowano wyniki pomiarów parametrów termofizycznych przegród izolacyj- \\ nych wytwarzanych w technologii druku 3D metodą osadzania topionego materiału FDM (ang. \\ fused deposition modelling), która jest jedną z metod przyrostowych szybkiego prototypowania. \\ Wytworzono próbki walcowe o średnicy 50,8 x $10 \mathrm{~mm}$ o różnym współczynniku wypełnienia \\ od 10 do $100 \%$. Próbki zostały wydrukowane z poliaktydu PLA (ang. polylactic acid, poly- \\ lactide). Dokonano pomiaru gęstości, współczynnika przewodzenia ciepła, współczynnika dyfuzyj- \\ ności cieplnej oraz ciepła właściwego. Celem eksperymentu było określenie wpływu współczyn-
}


nika gęstości wypełnienia, a pośrednio gęstości na współczynniki przewodzenia ciepła. W szczególności zastosowanie pustych przestrzeni wypełnionych powietrzem (porów) znacząco wpływa na zmianę współczynnika przewodzenia ciepła w stosunku do pełnego materiału. Wyniki badań mogą być przydatne do projektowania wszelkiego rodzaju przegród i obudów termoizolacyjnych wytwarzanych metodą szybkiego prototypowania, pracujących w stosunkowo niskich temperatu$\operatorname{rach}\left(<100^{\circ} \mathrm{C}\right)$.

Słowa kluczowe: szybkie prototypowanie, metoda FDM, przewodność cieplna, druk 3D

DOI: $10.7862 / \mathrm{rm} .2018 .02$

Otrzymano/received: 22.11 .2017

Zaakceptowano/accepted: 25.01.2018 